\title{
Differentiation between Actinobacillus (Haemophilus) actinomycetemcomitans, Haemophilus aphrophilus and Haemophilus paraphrophilus by multilocus enzyme electrophoresis
}

\author{
Dominique A. Caugant, ${ }^{1 *}$ Robert K. Selander ${ }^{2}$ and Ingar Olsen $^{3}$ \\ ${ }^{1}$ Department of Bacteriology, National Institute of Public Health, 0462 Oslo 4, Norway \\ ${ }^{2}$ Department of Biology, Pennsylvania State University, University Park, Pennsylvania 16802, USA \\ ${ }^{3}$ Department of Microbiology, Dental Faculty, University of Oslo, 0316 Oslo 3, Norway
}

(Received 12 March 1990; revised 13 June 1990; accepted 27 June 1990)

\begin{abstract}
Genetic relationships among isolates assigned to Actinobacillus actinomycetemcomitans, Haemophilus aphrophilus and $\boldsymbol{H}$. paraphrophilus were determined by analysis of electrophoretically demonstrable allelic variation in 14 structural genes encoding metabolic enzymes. Among the 51 isolates analysed there were 25 electrophoretic types (ETs), among which mean genetic diversity per locus was 0.753 . Cluster analysis of ETs demonstrated one welldefined group of 11 ETs representing solely the genotypes of all 17 isolates assigned to $A$. actinomycetemcomitans. The remaining 14 ETs represented the genotypes of the 34 isolates of $H$. aphrophilus and $H$.paraphrophilus. With the exception of ATCC 13252, all strains of $H$. aphrophilus were closely related, whereas strains assigned to $H$. paraphrophilus included distantly related lineages, some of which were similar to those of $H$. aphrophilus and should be assigned to this species. Thus, the study showed that there is no significant overall genetic similarity between $A$. actinomycetemcomitans and the two Haemophilus spp.
\end{abstract}

\section{Introduction}

Actinobacillus and Haemophilus species are currently attracting the attention of many clinical microbiologists and taxonomists. This particularly applies to $A$. actinomycetemcomitans, $H$. aphrophilus and $H$. paraphrophilus, partly because of the increasing frequency of their isolation from unusual clinical sites. A. actinomycetemcomitans and $\boldsymbol{H}$. aphrophilus have also been isolated from healthy gingiva and from gingivitis and periodontitis (Kraut et al., 1972; Kilian \& Schiøtt, 1975; Tanner et al., 1979). While there seems to be an association between the presence of $A$. actinomycetemcomitans in dental plaque and localized periodontitis in juveniles (Slots $e t$ al., 1980), the causal role of $H$. aphrophilus in that disease is negligible (Tempro \& Slots, 1986). A. actinomycetemcomitans has also been recovered from extra-oral diseases such as bacterial endocarditis, pericarditis, post-extraction and brain abscesses, urinary tract infections and vertebral osteomyelitis (for a review, see Kaplan et al., 1989). Similarly $H$. aphrophilus has been isolated from brain abscesses, meningitis, sinusitis, pneumonia, empyema, otitis media, wound and post-operative infec-

Abbreviation: ET, electrophoretic type. tions, arthritis and osteomyelitis (King \& Tatum, 1962; Sutter \& Finegold, 1970; Ellner et al., 1979). $H$. paraphrophilus, a member of the indigenous flora of the oral cavity and pharynx (Kilian \& Schiøtt, 1975), may be responsible for subacute endocarditis, paronychia, brain abscess, osteomyelitis of the jaw, appendicitis (Kilian \& Frederiksen, 1981) and arthritis (von Essen et al., 1987). Occasionally, this organism has also been isolated from urine and the vagina (Kilian \& Biberstein, 1984). The oral cavity may represent a spearhead of the infectious spread of these bacteria, as suggested by the association of endocarditis caused by $A$. actinomycetemcomitans with rapidly destructive periodontitis (Anolik et al., 1981).

Biochemical tests suggest that $\boldsymbol{A}$. actinomycetemcomitans and $H$. aphrophilus are very similar, and their taxonomic positions have been open to question (King \& Tatum, 1962). Kilian (1976) emphasized that these two species do not require haemin and NAD for growth, and therefore do not meet the criteria for inclusion in the genus Haemophilus. On the other hand, Potts et al. (1985) suggested, on the basis of DNA-DNA reassociation experiments and previous inclusions of $\mathrm{X}$ and $\mathrm{V}$ factor independent species in the genus Haemophilus, that $A$. actinomycetemcomitans should be reassigned to the genus Haemophilus as $\boldsymbol{H}$. actinomycetemcomitans. This was 
Table 1. Origins and sources of the strains of $A$. actinomycetemcomitans, $H$. aphrophilus and $H$. paraphrophilus investigated

\begin{tabular}{|c|c|c|c|c|}
\hline ET & Strain* & Received as & $\begin{array}{l}\text { Geographical } \\
\text { source }\end{array}$ & $\begin{array}{l}\text { Site of } \\
\text { isolation }\end{array}$ \\
\hline \multirow[t]{2}{*}{1} & FDC 511 & A. actinomycetemcomitans & USA, Mass. & Periodontitis \\
\hline & FDC N27 & A. actinomycetemcomitans & USA, Mass. & Periodontosis \\
\hline 2 & SUNY 75 & A. actinomycetemcomitans & USA, New York & Dental plaque \\
\hline 3 & HK 435 & A. actinomycetemcomitans & Denmark & Pus \\
\hline 4 & ATCC 29523 & A. actinomycetemcomitans & USA, Colorado & Blood \\
\hline 5 & FDC Y4 & A. actinomycetemcomitans & USA, Mass. & Periodontosis \\
\hline 6 & ATCC 29522 & A. actinomycetemcomitans & USA, Illinois & Mandibular abscess \\
\hline \multirow[t]{2}{*}{7} & NCTC 9709 & A. actinomycetemcomitans & Denmark & Lumbar abscess \\
\hline & $\begin{array}{l}\text { FDC } 2043 \\
\text { and FDC } 2097 \dagger\end{array}$ & A. actinomycetemcomitans & USA, Mass. & Periodontitis \\
\hline 8 & FDC M61 & A. actinomycetemcomitans & USA, Mass. & Periodontitis \\
\hline 9 & G1-G4† & A. actinomycetemcomitans & Norway & Periodontitis \\
\hline 10 & ATCC $33384 \ddagger$ & A. actinomycetemcomitans & Denmark & Lung abscess \\
\hline 11 & ATCC 29524 & A. actinomycetemcomitans & USA, Wash. & Chest aspirate \\
\hline 12 & ATCC $29241 \ddagger$ & H. paraphrophilus & UK & Paronychia \\
\hline 13 & HK 319 & H. paraphrophilus & Denmark & Dental plaque \\
\hline 14 & $\begin{array}{l}\text { IMoAI } \\
\text { and IMoAII } \dagger\end{array}$ & H. paraphrophilus & Norway & Cerebellar abscess \\
\hline 15 & ATCC 29240 & H. paraphrophilus & UK & Parietal abscess \\
\hline 16 & HK 477 & H. paraphrophilus & Denmark & Dental plaque \\
\hline \multirow[t]{3}{*}{17} & ATCC 19415 & H. aphrophilus & UK & Endocarditis \\
\hline & H76 & H. paraphrophilus & UK & Oral cavity \\
\hline & IIIRA43 & H. paraphrophilus & Norway & Sputum \\
\hline 18 & ATCC $33389 \ddagger$ & H. aphrophilus & UK & Endocarditis \\
\hline 19 & $\begin{array}{l}\text { FDC } 654 \\
\text { and FDC } 655+\end{array}$ & H. aphrophilus & USA, Mass. & Periodontitis \\
\hline \multirow[t]{3}{*}{20} & FDC 621 & H. aphrophilus & USA, Mass. & Periodontosis \\
\hline & FDC 626 & H. aphrophilus & USA, Mass. & Periodontosis \\
\hline & $1-15 \dagger$ & H. aphrophilus & Norway & Saliva \\
\hline 21 & HK 159 & H. paraphrophilus & Denmark & Saliva \\
\hline 22 & ATCC 13252 & H. aphrophilus & Unknown & Unknown \\
\hline 23 & HK 296 & H. paraphrophilus & Denmark & Chronic bronchitis \\
\hline 24 & HK 321 & H. paraphrophilus & Denmark & Dental plaque \\
\hline 25 & ATCC 29242 & H. paraphrophilus & Denmark & Trachea \\
\hline
\end{tabular}

* All the strains from Norway are recent clinical isolates. ATCC, American Type Culture Collection; FDC, Forsyth Dental Center; H, W. Sims, Royal Dental Hospital of London, UK; HK, M. Kilian, Royal Dental College, Aarhus, Denmark; NCTC, National Collection of Type Cultures (UK); SUNY, State University of New York. The 15 isolates of $H$. aphrophilus from Norway (ET 20) were collected from the saliva of one individual, using a selective medium (Tempro \& Slots, 1986).

$\dagger$ Multiple isolates from the same individual.

$\ddagger$ Type strain.

further supported by analysis of 16S rRNA sequences (Chuba et al., 1988; Paster et al., 1988). Tanner et al. (1982) found that $H$. paraphrophilus and $H$. aphrophilus strains, except for a single isolate of the former group, could not be distinguished as two separate species as there was overlap in biochemical characteristics and high degree of DNA-DNA homology. However, Brondz et al. (1990), using multivariate analyses of chemotaxonomic data, distinguished $\boldsymbol{A}$. actinomycetemcomitans, $\boldsymbol{H}$. aphrophilus and $H$. paraphrophilus.

In recent years, multilocus enzyme electrophoresis has been employed to assess genetic diversity and population structure in a number of bacterial species (Selander et al., 1986, 1987). The method is based upon electrophoretic detection of allelic diversity by indexing variation in the amino acid sequences of many gene products, the metabolic enzymes. Previous investigations have demonstrated that estimates of genetic relatedness based on multilocus enzyme electrophoresis are significantly correlated with measures of total genomic similarity as estimated by DNA-DNA hybridization (Ochman et al., 1983; Selander et al., 1985).

In the present study, we analyse allelic variation in 14 genes, to assess the genetic diversity among strains assigned to the species $A$. actinomycetemcomitans, $H$. aphrophilus and $H$. paraphrophilus, and to determine the relationships between isolates of the three species.

\section{Methods}

Bacterial isolates. A collection of 51 isolates was examined, comprising 17 strains of A. actinomycetemcomitans isolated from 13 hosts, 22 strains of $H$. aphrophilus from 7 hosts, and 12 strains of $H$. 
paraphrophilus from 11 hosts. All strains had originally been recovered from humans with or without clinical disease. The sources and designations of the strains are given in Table 1. Strain identification was based on growth requirement for haemin and NAD, acid and gas production from specific sugars, and other physiological characteristics (Tanner et al., 1982; Kilian \& Biberstein, 1984).

Preparation of culture lysates. The isolates were cultured anaerobically $\left(80 \% \mathrm{~N}_{2} / 10 \% \mathrm{H}_{2} / 10 \% \mathrm{CO}_{2}\right)$, usually in brain heart infusion broth (Difco), at $35^{\circ} \mathrm{C}$ for 2 or $3 \mathrm{~d}$. For $H$. paraphrophilus, the broth was supplemented with filter-sterilized NAD $\left(1 \mathrm{mg} \mathrm{l}^{-1}\right)$ and haemin $(5 \mathrm{mg}$ $\left.1^{-1}\right)$. H. paraphrophilus strains HK 321 and HK 296 grew poorly in this medium and were therefore grown on chocolate agar plates, harvested by scraping colonies off the plates, then washed and resuspended in phosphate-buffered saline, $\mathrm{pH} 7 \cdot 2$. The other strains were harvested by centrifugation of broth cultures $\left(5860 \mathrm{~g}\right.$ at $4{ }^{\circ} \mathrm{C}$ for $\left.20 \mathrm{~min}\right)$. The pellets were resuspended in $2 \mathrm{ml}$ phosphate-buffered saline. Cells were lysed by sonication, using a Branson Cell Disruptor with microtip at $50 \mathrm{~W}$ for $60 \mathrm{~s}$, with ice-cooling. After lysis and centrifugation at $25000 \mathrm{~g}$ at $4{ }^{\circ} \mathrm{C}$ for $30 \mathrm{~min}$, aliquots of supernatants were transferred to $1 \mathrm{ml}$ freeze tubes (Nunc) and stored immediately at $-70^{\circ} \mathrm{C}$ until electrophoresis.

Electrophoresis of enzymes. Lysates were electrophoresed on starch gels and selectively stained for 14 metabolic enzymes (Selander $e t$ al., 1986). Buffer system A was used for electrophoresis of malate dehydrogenase (MDH; EC 1.1.1.37), 6-phosphogluconate dehydrogenase (6PG; EC 1.1.1.44), glucose-6-phosphate dehydrogenase (G6P; EC 1.1.1.49), indophenol oxidase (IPO: EC 1.15.1.1; superoxide dismutase), adenylate kinase (ADK; EC 2.7.4.3), alkaline phosphatase (ALP; EC 3.1.3.1), phosphoglucose isomerase (PGI; EC 5.3.1.9), glutamate dehydrogenase (GDH; EC 1.4.1.4), phosphoglucomutase (PGM; EC 5.4.2.2), leucine aminopeptidase (LAP; EC 3.4.11.1), and succinate dehydrogenase (SDH; EC 1.3.99.1). Buffer system D was used for electrophoresis of peptidase (PEP; EC 3.4.-.-), aspartate dehydrogenase (ASP; EC 1 4.3.-) and fumarase (FUM; EC 4.2.1.2).

Electromorphs (mobility variants) of each enzyme, numbered in order of decreasing anodal mobility, were equated with alleles at the corresponding structural gene locus (see Table 2). An absence of enzyme activity was attributed to a null allele, designated as 0 . Each isolate was characterized by its profile of alleles at the 14 enzyme loci assayed, and distinctive combinations of alleles, representing multilocus genotypes, were designated as electrophoretic types, ETs (Selander et al., 1986).

Statistical analysis. Genetic diversity at an enzyme locus among ETs was calculated as $h=\left(1-\sum x_{i}^{2}\right)(n / n-1)$, where $x_{i}$ is the frequency of the $i$ th allele and $n$ is the number of ETs. Mean genetic diversity per locus $(H)$ is the arithmetic average of $h$ values over all loci. Genetic distance between pairs of ETs $(D)$ was expressed as the proportion of enzyme loci at which dissimilar alleles occurred. Null alleles were excluded from the measure of genetic distance. Clustering of ETs was performed from the matrix of genetic distances by the average-linkage method (Sneath \& Sokal, 1973).

\section{Results}

\section{Overall genetic diversity}

The ET of each strain is given in Table 1, and the allele profiles at 14 enzyme loci for a representative strain from each ET are shown in Table 2.

In the collection of 51 isolates examined, all 14 enzyme loci assayed were polymorphic for 4 (ASP) to 11 (PGM) alleles; the mean was 6.3 alleles per locus (Table 3 ). No ASP activity was demonstrated in the strains of $A$. actinomycetemcomitans, whereas all but two of the Haemophilus strains had ASP activity. The remaining 13 enzymes were expressed in at least $90 \%$ of the isolates. There were 25 ETs represented in the collection of isolates (Table 2), among which the mean genetic diversity per locus was 0.753 and the interlocus variance, $s^{2}$, was 0.006 (Table 3). A pairwise comparison of the electromorph profiles of the $25 \mathrm{ETs}$ revealed that $60 \%$ of the ET pairs differed at 11 or more of the enzyme loci assayed (mean, 10.12 loci; $s^{2}=18.45$ ), indicating that at least two very distinct groups of genotypes were represented among the 25 ETs (Fig. 1).

\section{Genetic diversity within species}

Eleven ETs were identified among the 17 isolates of $\boldsymbol{A}$. actinomycetemcomitans examined (Table 4). The four isolates (G1 through $\mathrm{G} 4)$ recovered from a single patient with periodontitis in Norway were identical (ET 9), as were the two isolates from a single individual with periodontitis in the USA, FDC 2043 and FDC 2097 (ET 7). Strain NCTC 9709 , isolated from a patient with lumbar abscess in Denmark, was also ET 7.

Five ETs were identified among the 22 isolates of $H$. aphrophilus (Table 4). The 15 isolates recovered from the saliva of a single individual in Norway were identical (ET 20), and belonged to the same ET as strains FDC 621 and FDC 626, recovered from two cases of periodontitis in the USA (Table 1). Isolates FDC 654 and FDC 655, obtained from a single individual with periodontitis, were also genetically identical (ET 19).

The 12 isolates assigned to $H$. paraphrophilus were of $10 \mathrm{ETs}$, among which mean genetic diversity per locus was 0.686 , that is $91 \%$ of the genetic diversity among the 25 ETs of the whole strain collection (Table 4). Whereas ETs of $\boldsymbol{A}$. actinomycetemcomitans and $\boldsymbol{H}$. aphrophilus differed at an average of 4.7 and 4.5 loci, respectively, the ETs of isolates assigned to $H$. paraphrophilus differed at an average of $8.6 \mathrm{loci}$, with $46 \%$ of the ET pairs having dissimilar alleles at 11 or more enzyme loci.

\section{Relationships among ETS}

The relationships among the 25 ETs are summarized by the dendrogram in Fig. 2. Genotypes differing solely in the occurrence of null alleles are represented by a single branch in the dendrogram, as null alleles were not included in the measure of genetic distance, $D$, between ETs. The smallest value of $D, 0.07$, corresponds to a single-locus difference between ETs. 
Table 2. Allele profiles at 14 enzyme loci in ETs of $A$. actinomycetemcomitans, $H$. aphrophilus and $H$. paraphrophilus

\begin{tabular}{|c|c|c|c|c|c|c|c|c|c|c|c|c|c|c|c|}
\hline \multirow[b]{2}{*}{ ET } & \multirow{2}{*}{$\begin{array}{l}\text { Reference } \\
\text { isolate }\end{array}$} & \multicolumn{14}{|c|}{ Alleles at indicated enzyme loci* } \\
\hline & & MDH & G6P & 6PG & IPO & GDH & ADK & PGM & PGI & LAP & FUM & PEP & ALP & ASP & SDH \\
\hline 1 & FDC N27 & 8 & 4 & 0 & 4 & 3 & 3 & 9 & 8 & 4 & 3 & 5 & 4 & 0 & 5 \\
\hline 2 & SUNY 75 & 8 & 4 & 0 & 4 & 3 & 0 & 9 & 8 & 4 & 3 & 5 & 4 & 0 & 5 \\
\hline 3 & HK 435 & 8 & 4 & 0 & 4 & 3 & 0 & 9 & 8 & 4 & 3 & 5 & 0 & 0 & 5 \\
\hline 4 & ATCC 29523 & 8 & 4 & 0 & 4 & 3 & 0 & 8 & 8 & 4 & 3 & 5 & 4 & 0 & 0 \\
\hline 5 & FDC Y4 & 5 & 4 & 4 & 4 & 1 & 3 & 9 & 2 & 4 & 3 & 5 & 3 & $\mathbf{0}$ & 0 \\
\hline 6 & ATCC 29522 & 5 & 4 & 4 & 4 & 1 & 3 & 9 & 2 & 4 & 3 & 5 & 3 & $\mathbf{0}$ & 4 \\
\hline 7 & NCTC 9709 & 5 & 4 & 4 & 4 & 1 & 3 & 9 & 2 & 4 & 3 & 5 & 1 & 0 & 4 \\
\hline 8 & FDC M61 & 5 & 4 & 0 & 4 & 1 & 3 & 9 & 2 & 4 & 3 & 5 & 1 & 0 & 4 \\
\hline 9 & Gl & 5 & 4 & 4 & 4 & 1 & 3 & 10 & 2 & 4 & 3 & 5 & 1 & 0 & 4 \\
\hline 10 & ATCC 33384 & 1 & 4 & 4 & 4 & 1 & 3 & 10 & 2 & 4 & 0 & 5 & 1 & 0 & 4 \\
\hline 11 & ATCC 29524 & 5 & 5 & 5 & 4 & 1 & 3 & 9 & 2 & 5 & 3 & 5 & 3 & $\mathbf{0}$ & 4 \\
\hline 12 & ATCC 29241 & 2 & 1 & 3 & 2 & 5 & 2 & 2 & 3 & 3 & 1 & 3 & 1 & 2 & 2 \\
\hline 13 & HK 319 & 2 & 0 & 3 & 2 & 5 & 0 & 1 & 3 & 0 & 2 & 3 & 0 & 0 & 2 \\
\hline 14 & IMoAI & 6 & 1 & 2 & 3 & 5 & 2 & 5 & 3 & 3 & 2 & 4 & 1 & 3 & 1 \\
\hline 15 & ATCC 29240 & 6 & 1 & 2 & 3 & 5 & 2 & 6 & 3 & 3 & 2 & 4 & 1 & 3 & 1 \\
\hline 16 & HK 477 & 6 & 1 & 2 & 3 & 5 & 2 & 6 & 0 & 3 & 2 & 4 & 1 & 3 & 2 \\
\hline 17 & ATCC 19415 & 6 & 1 & 1 & 2 & 4 & 2 & 4 & 3 & 3 & 2 & 4 & 1 & 3 & 2 \\
\hline 18 & ATCC 33389 & 6 & $i$ & 1 & 2 & 4 & 2 & 4 & 3 & 3 & 2 & 3 & 1 & 3 & 2 \\
\hline 19 & FDC 654 & 6 & 1 & 1 & 2 & 4 & 2 & 4 & 1 & 3 & 2 & 4 & 1 & 3 & 2 \\
\hline 20 & FDC 621 & 6 & 6 & 3 & 2 & 4 & 2 & 7 & 3 & 2 & 2 & 2 & 1 & 3 & 2 \\
\hline 21 & HK 159 & 3 & 1 & 4 & 3 & 5 & 2 & 2 & 7 & 2 & 2 & 3 & 1 & 3 & 1 \\
\hline 22 & ATCC 13252 & 6 & 6 & 1 & 2 & 2 & 0 & 1 & 7 & 3 & 4 & 3 & 0 & 0 & 2 \\
\hline 23 & HK 296 & 4 & 2 & 1 & 1 & 5 & 0 & 4 & 4 & 2 & 2 & 3 & 3 & 3 & 0 \\
\hline 24 & HK 321 & 5 & 3 & 1 & 2 & 0 & 3 & 8 & 6 & 2 & 2 & 4 & 3 & 3 & 5 \\
\hline 25 & ATCC 29242 & 7 & 2 & 1 & 0 & 6 & 1 & 3 & 5 & 1 & 6 & 1 & 2 & 1 & 3 \\
\hline
\end{tabular}

* Enzyme abbreviations: MDH, malate dehydrogenase; G6P, glucose-6-phosphate dehydrogenase; 6PG, 6-phosphogluconate dehydrogenase; IPO, indophenol oxidase; GDH, glumate dehydrogenase; ADK, adenylate kinase; PGM, phosphoglucomutase; PGI, phosphoglucose isomerase; LAP, leucine aminopeptidase; FUM, fumarase; PEP, peptidase; ALP, alkaline phosphatase; ASP, aspartate dehydrogenase; SDH, succinate dehydrogenase.

Table 3. Components of genetic diversity at 14 enzyme loci in ETs of A. actinomycetemcomitans, $H$. aphrophilus and $H$. paraphrophilus

\begin{tabular}{lcccc}
\hline \hline & & \multicolumn{3}{c}{ Variance component ${ }^{\dagger}$} \\
\cline { 3 - 5 } $\begin{array}{l}\text { Enzyme } \\
\text { locus* }\end{array}$ & $\begin{array}{c}\text { No. of } \\
\text { alleles }\end{array}$ & $\begin{array}{l}\text { Within } \\
\text { species }\end{array}$ & Total & $F_{\text {st }}$ \\
\hline MDH & 8 & 0.610 & 0.813 & 0.250 \\
G6P & 7 & 0.458 & 0.750 & 0.389 \\
6PG & 6 & 0.671 & 0.827 & 0.189 \\
IPO & 5 & 0.293 & 0.703 & 0.583 \\
GDH & 7 & 0.517 & 0.820 & 0.370 \\
ADK & 4 & 0.530 & 0.710 & 0.254 \\
PGM & 10 & 0.721 & 0.870 & 0.171 \\
PGI & 9 & 0.675 & 0.837 & 0.194 \\
LAP & 6 & 0.444 & 0.737 & 0.398 \\
FUM & 6 & 0.311 & 0.667 & 0.534 \\
PEP & 5 & 0.418 & 0.717 & 0.417 \\
ALP & 5 & 0.682 & 0.687 & 0.007 \\
ASP & 4 & 0.293 & 0.590 & 0.503 \\
SDH & 6 & 0.608 & 0.817 & 0.256 \\
Mean & 6.3 & 0.517 & 0.753 & 0.313 \\
\hline \hline
\end{tabular}

* See footnote to Table 2 .

$\dagger$ The within-species component of genetic variance estimates the probability of a mismatch of alleles at an enzyme locus for two ETs chosen randomly from the same species; the total variance is the
At a $D$ value of $0 \cdot 50$, which reflects average differences between ETs at 7 of the 14 enzyme loci, there were three clusters of ETs (designated A, B and C), and five branches represented by single ETs. Cluster A comprised the 11 ETs of A. actinomycetemcomitans. Cluster B comprised the ETs of two $H$. paraphrophilus isolates, HK 319 and ATCC 29241, isolated in Denmark and the UK, respectively. Cluster $\mathrm{C}$ was formed by two subgroups of ETs, branching at $D=0.42$, one (ET 14 to ET 16) including the ETs of four isolates of $H$. paraphrophilus and the other (ET 17 to ET 20) including the ETs of all but one $\boldsymbol{H}$. aphrophilus isolate. In addition to strain ATCC 19415 of $H$. aphrophilus, ET 17 was also represented by two isolates of $H$. paraphrophilus: $\mathrm{H} 76$ and IIIRA43. ET 21 (HK 159) joined cluster $\mathrm{C}$ at $D=$ 0.54 and clusters $B$ and $C$ joined at $D=0.57$. The ET of the remaining isolate of $H$. aphrophilus, ATCC 13252, clustered with B and C at $D=0.65$. The remaining three

comparable estimate for two ETs drawn from the pooled groups. $F_{s t}$ is the ratio of the probability of a mismatch for two ETs selected randomly from different species to the average probability in the pooled sample; it is thus a measure of the relative magnitude of genetic differentiation at an enzyme locus among groups. 
Table 4. Genetic diversity in ETs of A. actinomycetemcomitans, H. aphrophilus and H. paraphrophilus

\begin{tabular}{lccccc}
\hline \hline \multicolumn{1}{c}{ Species } & $\begin{array}{c}\text { No. of } \\
\text { isolates }\end{array}$ & $\begin{array}{c}\text { No. of } \\
\text { ETs }\end{array}$ & $\begin{array}{c}\text { No. of } \\
\text { polymorphic } \\
\text { enzymes }\end{array}$ & $\begin{array}{c}\text { Mean no. } \\
\text { of alleles } \\
\text { per locus }\end{array}$ & $\begin{array}{c}\text { Genetic } \\
\text { diversity } \\
\text { in ETs }\end{array}$ \\
\hline A. actinomycetemcomitans & 17 & 11 & 11 & $2 \cdot 2$ & $0 \cdot 369$ \\
H. aphrophilus & 22 & 5 & 11 & $2 \cdot 0$ & $0 \cdot 400$ \\
H. paraphrophilus & 12 & 10 & 14 & $4 \cdot 4$ & $0 \cdot 686$ \\
Total & 51 & 25 & 14 & $6 \cdot 3$ & 0.753 \\
\hline \hline
\end{tabular}

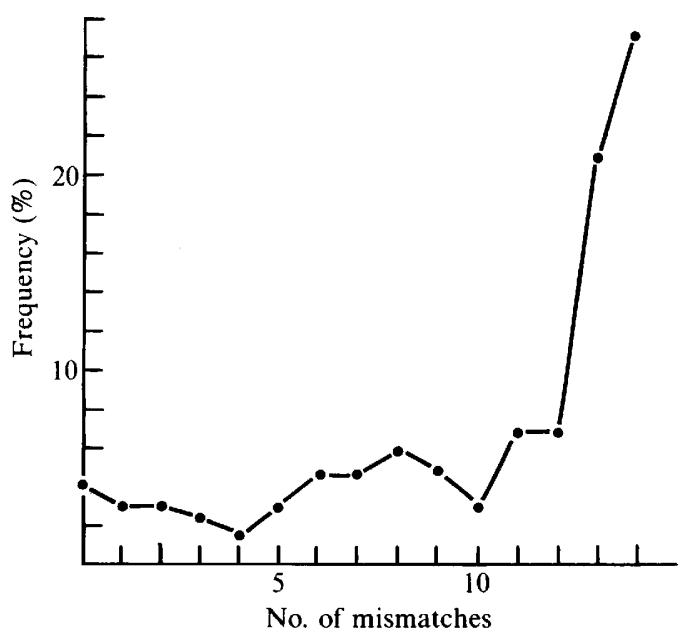

Fig. 1. Frequency of numbers of enzyme loci at which unlike alleles (mismatches) occurred in pairwise comparisons of $25 \mathrm{ETs}$ of 51 isolates of A. actinomycetemcomitans, $H$. aphrophilus and $H$. paraphrophilus.

ETs (ET 23 to 25 ) represented the genotypes of three isolates assigned to $H$. paraphrophilus (HK 296, HK 321 and ATCC 29242). Cluster A joined all the other ETs at $D=0.96$.

\section{Discussion}

DNA homology between strains of $A$. actinomycetemcomitans, $H$. aphrophilus and $H$. paraphrophilus has been studied by several investigators, with varying results (Tanner et al., 1982; Coykendall et al., 1983; Potts \& Berry, 1983). The survey of Tanner et al. (1982) included the largest portion of isolates examined by us. When the genetic similarity $(1-D)$ assessed by multilocus enzyme electrophoresis was compared with the percentage of DNA-DNA hybridization for 30 pairs of isolates (Tanner et al., 1982), there was a significant correlation $(r$ $=0.90, P<0.001)$ between relatedness obtained with the two methods. However, for all but one of the ten comparisons including one isolate of $A$. actinomycetemcomitans and one of the $H$. aphrophilus/H. paraphrophilus

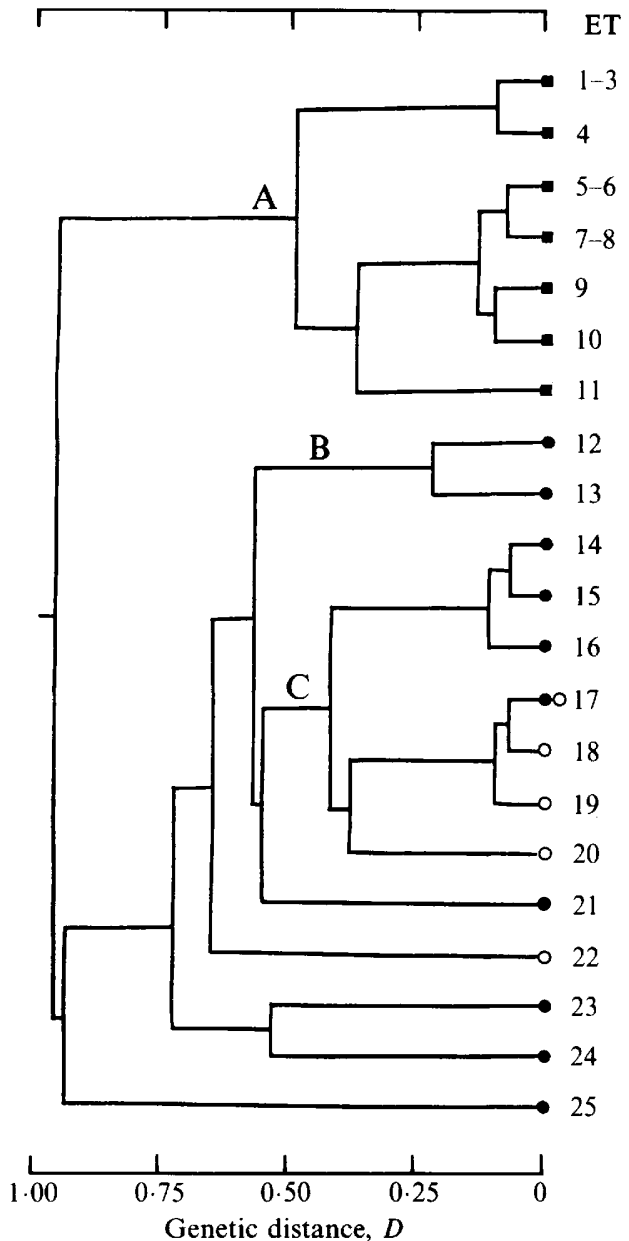

Fig. 2. Genetic relationships among ETs of A actinomycetemcomitans, $H$. aphrophilus and $H$. paraphrophilus. The dendrogram was generated by the average-linkage method of clustering from a matrix of coefficients of genetic distance between pairs of ETs, based on 14 enzyme loci. $\square$, ETs of $\boldsymbol{A}$. actinomycetemcomitans; O, ETs of $\boldsymbol{H}$. aphrophilus; ETs of $H$. paraphrophilus. A, B, and C indicate clusters of ETs that diverge at a genetic distance of less than 0.50 .

group the similarity from multilocus enzyme electrophoresis was null. Considering only the 20 within-species pairwise comparisons, the correlation was less, but still 
significant $(r=0.71, P<0.001)$. The estimates of genetic distance based on the sample of 14 enzyme loci assayed should therefore be representative of the overall genomic relationships between strains.

The electrophoretic analysis of allelic variation at 14 enzyme loci confirmed previous lines of evidence derived from electrophoresis of total proteins (Jellum et al., 1984; Olsen et al., 1987) and DNA-DNA reassociation experiments (Pohl, 1981; Tanner et al., 1982; Coykendall et al., 1983; Potts \& Berry, 1983) that there is no large total genetic similarity between strains of $\boldsymbol{A}$. actinomycetemcomitans and $H$. aphrophilus. Although the number of strains of each species analysed was relatively small, isolates were obtained from various geographical areas. Thus, it is likely that the genetic diversity among ETs observed is representative of that in these species. It should be noted that the computation of the genetic diversity is based on the ETs and therefore is not affected by the inclusion of multiple isolates from the same host.

The diversity among genotypes of A. actinomycetemcomitans and $H$. aphrophilus was similar to that reported for other bacterial species (Musser et al., 1986). In contrast, the $10 \mathrm{ETs}$ of the 12 isolates of $H$. paraphrophilus we studied were more diverse than the 331 ETs of 688 isolates of Neisseria meningitidis, which is the most variable bacterial species analysed by multilocus enzyme electrophoresis thus far (Caugant et al., 1987). This suggests that the isolates assigned to $H$. paraphrophilus in fact belong to several species.

Of the three most distinctive isolates in this study, $\mathrm{HK}$ 296 and HK 321 have been tentatively assigned to $H$. paraphrophilus (Kilian, 1976), although they differed from other strains of this species in several biochemical and physiological properties. This was also indicated by our inability to grow these isolates in broth cultures. Electrophoretic mobilities are not influenced by growth conditions (Musser et al., 1986; Selander et al., 1986); thus the differences observed between HK 296 and HK 321 and other $H$. paraphrophilus strains are not likely to be artefacts but reflect genetic dissimilarity. ATCC 29242 has been reported atypical of $H$. paraphrophilus in its protein pattern in two-dimensional electrophoresis (Olsen et al., 1987), biochemical characteristics, G+C content, and homology to other strains of the species as measured by DNA-DNA reassociation (Tanner et al., 1982). Multilocus enzyme electrophoresis clearly confirmed that ATCC 29242 is not a member of the species H. paraphrophilus.

When these three atypical isolates (HK 296, HK 321 and ATCC 29242) were excluded from data evaluation, strains of $H$. aphrophilus and $H$. paraphrophilus formed a genetically homogeneous group of 11 ETs among which genetic diversity per locus was 0.526 . There were then no significant differences in allele frequencies between the two species for 8 of the 14 enzymes assayed, and the magnitude of genetic differentiation between ETs of isolates of $H$. aphrophilus and those of $H$. paraphrophilus was only 0.042 , as measured by $F_{\text {st }}$ (see Table 3 ). This similarity supports evidence from DNA-DNA hybridization experiments (Tanner et al., 1982; Potts et al., 1986) and two-dimensional electrophoresis of total proteins (Olsen et al., 1987). However, there are differences between $H$. aphrophilus and $H$. paraphrophilus in NAD dependence, biochemical reactions (Kilian \& Biberstein, 1984) and cellular sugars (Brondz et al., 1990).

The recovery of ET 7 of $A$. actinomycetemcomitans in Denmark and the USA, and the occurrence of the same ETs of $H$. aphrophilus in the UK and Norway (ET 17) and in Norway and the USA (ET 20), suggests that populations of $A$. actinomycetemcomitans and $H$. aphrophilus are clonal in structure. Like most bacterial species so far analysed by multilocus enzyme electrophoresis (Selander et al., 1987), clones of $H$. aphrophilus are temporally stable, as demonstrated by the representation of ET 17 by ATCC 19415 isolated in 1938 in the UK, and by IIIRA43 isolated in 1986 in Norway.

The closely related clones of $A$. actinomycetemcomitans, ET 1 to ET 4, were represented by isolates recovered from blood, pus, dental plaques and periodontal pockets, and ET 7 was recovered from patients with periodontitis and lumbar abscess. Similarly, ET 17 of $H$. aphrophilus was represented by an isolate from the oral cavity and another from blood. It is thus likely that these organisms had a common source, probably dental plaque, to the indigenous flora of which A. actinomycetemcomitans and $H$. aphrophilus belong. Dissemination of oral bacteria to the bloodstream is not a rare event and both accumulation of dental plaque and periodontal inflammation increase the frequency of bacteraemic conditions.

We thank Dr L. O. Frøholm for valuable discussions, and Drs $\mathrm{K}$. Bøvre, J. Eng, M. Kilian and H. R. Preus for providing bacterial strains. We acknowledge the technical assistance of S. Dynna and C. Fleming. This project was supported by Public Health Service grant AI 24631 from the National Institutes of Health to R.K.S. and grant 13.48.07-026 from the Norwegian Council for Science and Humanities to D.A.C.

\section{References}

Anolik, R., Berkowitz, R. J., Campos, J. M. \& Friedman, A. D. (1981). Actinobacillus endocarditis associated with periodontal disease. Clinical Pediatrics 20, 653-655.

BrondZ, I., OlsEN, I. \& SJÖSTRÖM, M. (1990). Multivariate analysis of quantitative chemical and enzymic characterization data in classification of Actinobacillus, Haemophilus and Pasteurella spp. Journal of General Microbiology 136, 507-513. 
Caugant, D. A., Mocca, L. F., Frasch, C. E., Frøholm, L. O., ZOLLINGER, W. D. \& Selander, R. K. (1987). Genetic structure of Neisseria meningitidis populations in relation to serogroup, serotype, and outer membrane protein pattern. Journal of Bacteriology 169, 2781-2792.

Chuba, P. J., Bock, R., Graf, G., Adam, T. \& Göbel, U. (1988). Comparison of $16 \mathrm{~S}$ rRNA sequences from the family Pasteurellaceae: phylogenetic relatedness by cluster analysis. Journal of General Microbiology 134, 1923-1930.

CoYkendali, A. L., SeTterfield, J. \& Slots, J. (1983). Deoxyribonucleic acid relatedness among Actinobacillus actinomycetemcomitans, Haemophilus aphrophilus and other Actinobacillus species. International Journal of Systematic Bacteriology 33, 422-424.

Ellner, J. J., Rosenthal, M. S., Lerner, P. I. \& McHenry, M. C. (1979). Infective endocarditis caused by slow-growing, fastidious, gram-negative bacteria. Medicine 58, 145-158.

von Essen, R., Kostiala, A. A. I., ANTtolainen, I., HaApasaAri, J. \& SivoNEN , A. (1987). Arthritis caused by Haemophilus paraphrophilus: isolation of the organism by using an improved culture protocol. Journal of Clinical Microbiology 25, 2447-2448.

Jellum, E., Tingelstad, V. \& Olsen, I. (1984). Differentiation between Actinobacillus actinomycetemcomitans and Haemophilus aphrophilus by high-resolution, two-dimensional protein electrophoresis. International Journal of Systematic Bacteriology 34, 478-483.

Kaplan, A. H., Weber, D. J., Oddone, B. Z. \& Perfect, J. R. (1989). Infection due to Actinobacillus actinomycetemcomitans: 15 cases and review. Reviews of Infectious Diseases 11, 46-63.

KiLIAN, M. (1976). A taxonomic study of the genus Haemophilus, with the proposal of a new species. Journal of General Microbiology 93, 9 62 .

Kilian, M. \& Biberstein, E. L. (1984). Genus II. Haemophilus Winslow, Broadhurst, Buchanan, Krumwiede, Rogers and Smith 1917, 561 AL. In Bergey's Manual of Systematic Bacteriology, vol. 1, pp. 558-560. Edited by N. R. Krieg \& J. G. Holt. Baltimore \& London: Williams \& Wilkins.

Kilian, M. \& Frederiksen, W. (1981). Ecology of Haemophilus, Pasteurella and Actinobacillus. In Haemophilus, Pasteurella and Actinobacillus, pp. 11-38. Edited by M. Kilian, W. Frederiksen \& E. L. Biberstein. London: Academic Press.

KILIAN, M. \& SCHIøTT, C. R. (1975). Haemophili and related bacteria in the human oral cavity. Archives of Oral Biology 20, 791-796.

KING, E. O. \& TATUM, H. W. (1962). Actinobacillus actinomycetemcomitans and Haemophilus aphrophilus. Journal of Infectious Diseases 111, 85-94.

Kraut, M. S., Attebery, H. R., Finegold, S. M. \& Sutter, V. L. (1972). Detection of Haemophilus aphrophilus in the human oral flora with selective medium. Journal of Infectious Diseases 126, 189-192.

Musser, J. M., Hewlett, E. L., Pepler, M. S. \& Selander, R. K. (1986). Genetic diversity and relationships in populations of Bordetella spp. Journal of Bacteriology 166, 230-237.

Ochman, H., Whittam, T. S., Caugant, D. A. \& Selander, R. K. (1983). Enzyme polymorphism and genetic population structure in Escherichia coli and Shigella. Journal of General Microbiology 129, 2715-2726.

Olsen, I., Rosseland, S. K., Thorsrud, A. K. \& Jellum, E. (1987) Differentiation between Haemophilus paraphrophilus, H. aphrophilus,
H. influenzae, Actinobacillus actinomycetemcomitans, Pasteurella multocida, $P$. haemolytica, and $P$. ureae by high resolution twodimensional protein electrophoresis. Electrophoresis 8, 532-535.

Paster, B. J., DeWhirst, F. E. \& Olsen, I. (1988). The phylogeny of Actinobacillus, Haemophilus and Pasteurella by its 16S rRNA sequencing. Journal of Dental Research 67, special issue, abstract no. 2259 , p. 395.

PoHL, S. (1981). DNA relatedness among members of Haemophilus, Pasteurella and Actinobacillus. In Haemophilus, Pasteurella and Actinobacillus, pp. 245-253. Edited by M. Kilian, W. Frederiksen \& E. L. Biberstein. London: Academic Press.

PotTs, T. V. \& BerRy, E. M. (1983). Deoxyribonucleic aciddeoxyribonucleic acid hybridization analysis of Actinobacillus actinomycetemcomitans and Haemophilus aphrophilus. International Journal of Systematic Bacteriology 33, 765-771.

PotTs, T. V., ZAMBON, J. J. \& GenCo, R. J. (1985). Reassignment of Actinobacillus actinomycetemcomitans to the genus Haemophilus as Haemophilus actinomycetemcomitans comb. nov. International Journal of Systematic Bacteriology 35, 337-341.

PotTs, T. V., Mitra, T., O'Keefe, T., Zambon, J. J. \& Genco, R. J. (1986). Relationships among isolates of oral haemophili as determined by DNA-DNA hybridization. Archives of Microbiology 145, 136-141.

Selander, R. K., McKinney, R. M., Whittam, T. S., Bibb, W. F., Brenner, D. J., Nolte, F. S. \& Pattison, P. E. (1985). Genetic structure of populations of Legionella pneumophila. Journal of Bacteriology 163, 1021-1037.

Selander, R. K., Caugant, D. A., Ochman, H., Musser, J. M., Gilmour, M. N. \& WhitTAM, T. S. (1986). Methods of multilocus enzyme electrophoresis for bacterial population genetics and systematics. Applied and Environmental Microbiology 51, 873-884.

Selander, R. K., Musser, J. M., Caugant, D. A., Gilmour, M. N. \& WhITTAM, T. S. (1987). Population genetics of pathogenic bacteria. Microbial Pathogenesis 3, 1-7.

Slots, J., Reynolds, H. S. \& Genco, R. J. (1980). Actinobacillus actinomycetemcomitans in human periodontal disease: a crosssectional microbiological investigation. Infection and Immunity 29, 1013-1020.

SNEath, P. H. A. \& Sokal, R. R. (1973). Numerical Taxonomy. San Francisco: Freeman.

SUTTER, V. L. \& FINEGOLD, S. M. (1970). Haemophilus aphrophilus infections: clinical and bacteriological studies. Annals of the New York Academy of Sciences 174, 468-487.

Tanner, A. C. R., Haffer, C., Bratthall, G. T., Visconti, R. A. \& SOCRANSKY, S. S. (1979). A study of the bacteria associated with advancing periodontitis in man. Journal of Clinical Periodontology 6. 278-307.

Tanner, A. C. R., Visconti, R. A., Socransky, S. S. \& Holt, S. C. (1982). Classification and identification of Actinobacillus actinomycetemcomitans and Haemophilus aphrophilus by cluster analysis and deoxyribonucleic acid hybridizations. Journal of Periodontal $\mathbf{R e}$ search 17, 585-596.

TEMPRO, P. J. \& SLOTS, J. (1986). Selective medium for the isolation of Haemophilus aphrophilus from the human periodontium and other oral sites and the low proportion of the organism in the oral flora. Journal of Clinical Microbiology 23, 777-782. 